On the 7 th the patient requested leave to quit the hospital. The region of the spleen is slightly painful, although the organ does not appear to be enlarged.

French Lancet, Dec. 9th, 1837.

\section{ARSENIC IN CANDLES.}

To the Editor of THE LANCET.

Sir :-Having been absent from town since the 25 th of November, I was not aware, until my return, that $I$ had allowed my desire of condensing my information, to lead me into a misstatement in my communication, which you did me the honour to insert, on the above date, in your pages. In. stead of saying, that I had detected arsenic in spermaceti candles, $I$ should have said that I had done so in candles sold to my servant as spermaceti, the nature of which I did not detect until they were in use, but which were the stearine lights. I have the pleasure of subscribing myself, Sir, your obedient servant,

32, Newgate-street, Dec. 18, 1837.

Robert Hunt.

\section{QUACK MEDICINES.}

\section{To the Editor of THE LANCET.}

Sir :-There is a new system adopted by the puffers of nostrums, which, in the country, must operate very injuriously to the public. The other day, travelling in the country, I met with a person who, in proof of the good performed by a quack medicine, pullea out of his pocket a hand-bill, in which were stated the opinions of the leading journals of the metropolis, of course highly laudatory of the nostrum in question. The plan formed to deceive the public is as follows:-An advertisement is sent to, perhaps, half a dozen of the leading journals, containing the puff intended to be republished in the hand-bills of the advertiser. As soon, however, as the advertisement has appeared, it is printed on the hand-bills as if coming from the editor of the paper in which it was inserted as an advertisement, and thus many ignorant persons really believe it to be the opinion of that journal. I am, Sir, your obedient servant,

London, Dec. 5, 1837.

\section{A Constant Reader.}

Analysis of Iron Oras.-Berzelius states the following to be a rapid mode of analysing these ores. He boils them with chloride of copper, slightly acidulated with muriatic acid, then on boiling the residue with carbonate of soda, washing the result, drying and weighing, its weight indicates that of the carbon.

\section{NOTICE OF OPERATIONS.}

\section{To the Editor of The Lancet.}

Srr:-Knowing that you are ever anxious to reform all abuses which exist in our hospitals, I beg to inform you, that in the University College Hospital, it is notorious that the students are always ignorant when any operations are to be performed, from the want of proper notice being given; and unless they happen to be casually informed of them by the porter, they lose all chance of being benefitted thereby. Trusting that this communication will meet the observation of the authorities who can obviate the necessity for further complaint, $I$ remain, yours respectfully.
Dec. 18th, 1837.
J.C. C.

Assafotida in Hooping-covgh, - Dr. Dürr strongly recommends the use of assafoetida, in the form of clyster, in cases of hooping-cough. The period of the disease is considerably abridged by this remedy; and, after a lapise of two, or at most three weeks, the cough becomes so mild, that all danger of consequent affection of the lungs is almost entirely prevented.

\section{TO CORRESPONDENTS.}

$W_{E}$ have received numerous and contra. dictory communications on the subject of an alteration in the laws relating to the practice of pharmacy in Ireland, but as the pre. cise nature of the proposed changes can be better understood when the applicants are actually before Parliament, we refrain at present from all discussions of the questions mooted by either party.

If $\boldsymbol{A}$ Medical Friend can give evidence in proof of the statements contained in his letter, he should forward his name and ad. dress, with a reiteration of the facts to which he can testify.

We thank $A$ Pupil, but a pitier, of Mr. S. Cooper, for his communication, which we have not been able to find room this week to insert.

Mr. Edmunds, surgeon, of Kineton, Warwickshire, has addressed to us a letter, in which, with a view to clear Dr. James Johnson from the imputation of professional avarice, he testifies to the gratuitous services of Dr. Johnson in Mr. E.'s own case.

Letters and communications have been received from A Fresh Surgeon; Mr. Lovegrove; J. H.; Mr. F. Wilson; Chirirgus; Mr. Binham; and Mr. H. Rees.

In the press, "Velpeau's Anatomy of Regions," translated from the French, with notes, by Henry Hancock, M.R.C.S., Lecturer on Anatomy and Physiology at the Westminster Hospital School of Medicine. 